\title{
Evaluation of Bacillus thuringiensis Berliner as an alternative control of small hive beetles, Aethina tumida Murray (Coleoptera: Nitidulidae)
}

\author{
Sven Buchholz • Peter Neumann • Katharina Merkel • \\ H. Randall Hepburn
}

Received: 1 February 2006 / Accepted: 10 July 2006 / Published online: 15 August 2006

(C) Springer-Verlag 2006

\begin{abstract}
Small hive beetles, Aethina tumida Murray, are parasites and scavengers of honeybee colonies, Apis mellifera L., and have become an invasive species that can cause considerable damage in its new distribution areas. An effective subspecies of Bacillus thuringiensis Berliner $(=B t)$ would provide an alternative to chemical control of this pest. Therefore, we tested three different $B t$ strains [B. thuringiensis, var. aizawai $\left(\mathrm{B} 401^{\circledR}\right)$, B. thuringiensis var. kurstaki $\left(\right.$ Novodor $\left.^{\circledR}\right)$ and B. thuringiensis var. San Diego tenebrionis $\left(\right.$ Jackpot $\left.^{\circledR}\right)$ ] and Perizin ${ }^{\circledR}$ (3.2\% coumaphos), each applied on combs with a pollen diet fed to pairs of adult beetles. This evaluates the products for the suppression of successful small hive beetle reproduction. While none of the tested $B t$ strains showed a significant effect on the number of produced wandering larvae, we could
\end{abstract}

Communicated by Jürgen Gross

S. Buchholz $\cdot$ K. Merkel

Institut für Zoologie, Martin-Luther-Universität,

Halle-Wittenberg, 06099 Halle (Saale), Germany

P. Neumann $(\square)$

Swiss Bee Research Centre, Swiss Federal Research Station for Animal Production and Dairy Products (ALP),

CH-3003 Bern, Switzerland

e-mail: peter.neumann@alp.admin.ch

P. Neumann $\cdot$ H. R. Hepburn

Department of Zoology and Entomology,

Rhodes University, 6140 Grahamstown, South Africa

P. Neumann $\cdot$ H. R. Hepburn

Eastern Bee research Institute of Yunnan Agricultural

University, Heilongtan, Kunming,

Yunnan Province, China confirm the efficacy of coumaphos for the control of small hive beetles. We further show that it is also efficient when applied with a lower concentration as a liquid on the combs. We suggest the continued search for efficient $B t$ strains naturally infesting small hive beetles in its endemic and new ranges, which may become a part of the integrated management of this pest.

Keywords Aethina tumida B Bacillus thuringiensis . Coumaphos · Honeybee - Integrated pest management . Small hive beetle

\section{Introduction}

The small hive beetle (=SHB), Aethina tumida Murray, is a parasite and scavenger of honeybee colonies, Apis mellifera L., native to Sub-Saharan Africa (Hepburn and Radloff 1998). It has recently become an invasive species in North America (1996), Egypt (2000) and Australia (2002; cf. Neumann and Elzen 2004). In North America, it continues to cause considerable damage in the populations of Europeanderived honeybees (Elzen et al. 1999; Hood 2004). Adults and larvae of $A$. tumida can be successfully controlled in beehives with coumaphos as a contact agent using Check-Mite $+{ }^{\mathrm{TM}}$ strips (Bayer Healthcare AG, containing $10 \%$ coumaphos). The authors used the Check-Mite $+{ }^{\mathrm{TM}}$ plastic strips, cut in half and attached under bottom board trapping devices made of cardboard (Elzen et al. 1999). Check-Mite $+{ }^{\mathrm{TM}}$ strips were initially applied for the control of the parasitic mite, Varroa destructor Anderson and Trueman. However, such conventional control carries 
the risk of pest resistance, as has already occurred in $V$. destructor (Pettis 2003). Moreover, chemical residues may accumulate in the bee products (Neumann and Elzen 2004).

Bacillus thuringiensis Berliner $(=B t)$ is efficiently used in a wide range of different integrated pest management programs. The $B t$ bacterium produces proteinaceous crystals encoded by cry genes during sporulation, which become toxic when digested by insects. Parts of the dissolved crystals bind to midgut glucoprotein receptors and subsequently toxic molecules are inserted into the plasma membrane, forming pores that cause changes in ion flux. The resulting osmotic swelling and lysis of midgut epithel cells eventually lead to the death of susceptible pest organisms (Krieg 1986; Gill et al. 1992). Toxic crystals of Bt strains containing the cryII gene are successfully used in biological control systems, mostly against larvae of certain Lepidopteran and Dipteran pests. Some $B t$ strains are also efficacious against coleopteran larvae (Slaney et al. 1992), which seem to be mostly susceptible to crystal proteins (cry) encoded by cryIII genes (Höfte and Whiteley 1989). According to the considerable selectivity of $B t$ toxins (Höfte and Whiteley 1989; Schnepf et al. 1998), even closely related species will not be affected (Slaney et al. 1992), making Bt a suitable, as well as one of the most successful biological control agents. Aiming towards substitution of solely chemical control, we here evaluate the efficacy of commercially available products containing different $B t$ strains as an alternative control of SHB. Since the feeding larvae are the most destructive live stage of SHB, we concentrate on the ability of $B t$ to inhibit successful reproduction of SHB.

\section{Materials and methods}

The following products containing different $B t$ strains were tested to determine their efficacy against SHB.

1. $\mathrm{B} 401^{\circledR}$, a biological larvicide used against wax moths, Galleria mellonella L., which contains deltaendotoxins of $B$. thuringiensis var. aizawai, serotype 7.

2. Jackpot ${ }^{\circledR}$, containing B. thuringiensis var. kurstaki, which is used to control several Lepidopteran species,

3. Novodor $^{\circledR}$, based on B. thuringiensis var. San Diego tenebrionis, which is used against larvae of the Colorado potato beetle, Leptinotarsa decemlineata (Say) and of the Elm leaf beetle, Pyrralta luteola Muller.
We also tested Perizin ${ }^{\circledR}$ (3.2\% coumaphos) in a liquid application form because Check-Mite $+{ }^{\mathrm{TM}}$ strips containing coumaphos $(10 \%)$ were successfully used as a contact treatment against SHB (Elzen et al. 1999). Water was used as a negative control. As we did not assume an effect of $B t$ on adult SHB, we used the most practicable procedure to get 1st instar larvae on the food source by giving beetles the possibility to feed, mate and oviposite on treated combs. If the beekeeper would apply this method in the field, he would also spray the combs in the beehive with all stages of SHB present.

The experiments were conducted in February 2004 and 2005 in an environmental chamber $\left[+30^{\circ} \mathrm{C}\right.$ in permanent darkness] at Rhodes University (Grahamstown, Eastern Cape Province, South Africa). Adult SHB were reared on honeybee products using standard protocols (Neumann et al. 2001; Muerrle and Neumann 2004). Newly emerging beetles were sexed (Schmolke 1974) and kept in separate containers of their own sex with food ad lib (honey and water on cotton wool) to prevent mating prior to the experiments. Pieces of empty comb, filled with $5 \mathrm{~g}$ pollen as a protein source (Ellis et al. 2002), were sprayed with the $B t$ products, Perizin ${ }^{\circledR}$ or water $\left[0.5 \mathrm{ml} \mathrm{H}_{2} \mathrm{O}\right.$ as control] according to the instructions of the respective supplier, using a manual plastic pump sprayer. The combs were placed in plastic containers [Ziplock, $946 \mathrm{ml}$ ] and five pairs of adult SHB were added to each container. Round holes [ $\varnothing 5.5 \mathrm{~cm}$ ] covered with pieces of gauze $[12 \times 12 \mathrm{~cm}$, mesh width $\leq 0.50 \mathrm{~mm}]$ provided air and prevented adult and larval escape.

For the evaluation of $\mathrm{B} 401{ }^{\circledR}(0.5 \mathrm{ml}$ of $5 \%$ solution $)$ and $\operatorname{Perizin}^{\circledR} \quad\left[0.2 \mathrm{ml} \quad\left(\right.\right.$ Perizin $^{\circledR} \quad 3.2 \%: \quad \mathrm{H}_{2} \mathrm{O}$, $1: 50)+0.3 \mathrm{ml} \mathrm{H}_{2} \mathrm{O}$ ] in 2004, the adult SHB of both treatments and control $(N=5$ replicates each) were given 5 days for feeding, mating and oviposition on the combs $[8 \times 5 \mathrm{~cm}]$ before their removal. When the emerging offspring have consumed the treated food, untreated pollen was provided ad lib until the larvae reached the wandering phase (Schmolke 1974). Water was sprayed daily on the combs using a manual pump sprayer to ensure adequate humidity for larval development. The reproductive success in each treatment and in the controls was evaluated by counting all wandering larvae after 16 days.

As we did not intend to compare the results from experiments using different beetle populations, we modified the protocol of the experiments from 2004 as follows. In 2005 we observed that considerable oviposition by female SHB occurred already after $24 \mathrm{~h}$. For testing $B$. thuringiensis var. tenebrionis and B. thuringiensis var. kurstaki adult SHB in both treatments $(0.5 \mathrm{ml}$ of 
$10 \% \mathrm{Bt}$ solution each $)$ and in the control $\left(0.5 \mathrm{ml} \mathrm{H}_{2} \mathrm{O}\right)$ ( $N=8$ replicates each) 2 days were given for feeding, mating and oviposition on the combs $[5 \times 5 \mathrm{~cm}]$ instead of 5 days as in 2004, before they were removed. All wandering larvae were counted 15 days later, which is an adequate time window for reaching the wandering phase under the given environmental conditions.

Due to the different experimental designs in 2004 and 2005 the numbers of wandering larvae were compared exclusively within each experiment using Kruskal-Wallis ANOVAs, level of significance $P=0.05$. Mann-Whitney $U$ tests were used as post hoc tests with $P=0.0167$ as the Bonferroni-Fischer adjusted level of significance. All statistical analyses were conducted using the program STATISTICA ${ }^{\circledR}$.

\section{Results}

Significant differences were found between the number of wandering larvae after the application of Perizin ${ }^{\circledR}$ and $\mathrm{B} 401^{\circledR}$ (Kruskal-Wallis ANOVA: $H(2, N=15)$ $=9.428675, P<0.0089$; Fig. 1$)$. While the number of offspring in the B $401{ }^{\circledR}$ treatment $(204.4 \pm 59.7)$ was not significantly different from the control $(194.8 \pm 33.1$; Mann-Whitney $U$ test $Z=-0.209, P>0.834)$, the number of wandering larvae in the Perizin ${ }^{\circledR}$ treatment $(11.4 \pm 17.2)$ was significantly less compared to both the control and the B $401{ }^{\circledR}$ treatment (for both: MannWhitney $U$ test $Z=-2.611, P<0.0089)$. No significant differences were found between the number of wandering larvae from the $B$. thuringiensis var. tenebrionis $(293.6 \pm 144.9)$ and $B$. thuringiensis var. kurstaki $(395.3 \pm 103.6)$ treatments and the control (345.3 \pm 2.9 ; Kruskal-Wallis ANOVA: $H(2, N=24)=2.822$, $P>0.243)$.

\section{SHB larvae [n]}

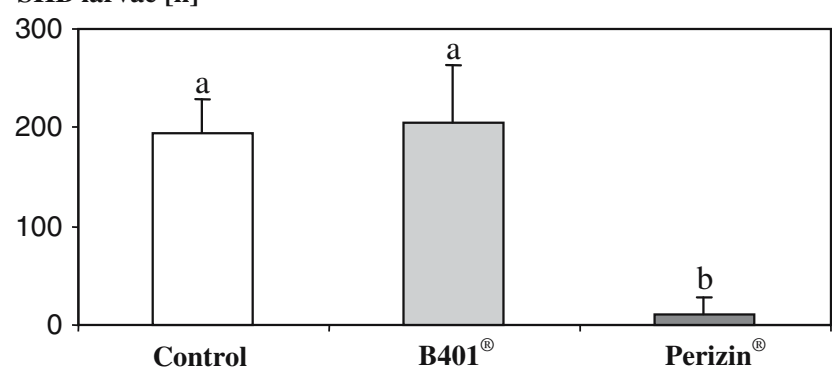

Fig. 1 Number of wandering SHB larvae (mean \pm SD) after 16 days in controls and in the treatments with Perizin ${ }^{\circledR}$ and B 401 ${ }^{\circledR}$. Different letters indicate significant differences $(P<0.0089)$ using Mann-Whitney $U$ tests as post hoc tests

\section{Discussion}

Our data give strong support to earlier studies (Elzen et al. 1999) that successful reproduction of SHB can be effectively reduced with coumaphos. While Elzen et al. (1999) used coumaphos as a contact treatment in bottom board trapping devices with Check-Mite $+{ }^{\mathrm{TM}}$ strips in higher concentrations $(10 \%)$, we applied it in a lower concentration $(3.2 \%)$ as a liquid directly on the combs $\left(\right.$ Perizin $\left.{ }^{\circledR}\right)$. However, the mode of action of coumaphos in SHB remains to be investigated, as it is not clear, whether reproduction was reduced by oviposition failure of female SHB or by mortality of successfully hatched larvae. Regardless of the actual underlying effect and of the mode of application [ingested (this study) or as a contact agent (Elzen et al. 1999)], coumaphos seems to provide an efficient control suppressing SHB reproduction even at lower concentrations.

Despite their active toxin crystal type cryII, we tested Lepidopteran-specific $B t$ products (Jackpot $^{\circledR}$ and $\mathrm{B} 401^{\circledR}$ ) because the efficiency of strains against coleopteran species cannot be predicted from the crystal morphology (Bernhard et al. 1997). Bt tenebrionis and Bt kurstaki, which are used to control other beetle pests, were also tested. However, none of the tested $B t$ strains were efficient against SHB, supporting the notion of strain-dependant insect selectivity of $B t$ (Höfte and Whiteley 1989; Slaney et al. 1992). Furthermore, it is safe to assume that the tested $B t$ products have not been applied before in South Africa against SHB. So we can also rule out that resistance against these $B t$ strains has been developed as known from other pest species (Tabashnik 1994).

Further investigation would require to test more $B t$ strains, which are used to control other beetle pests. Another promising approach appears to be the development of new strains (Feitelson et al. 1992; Naimov et al. 2001), which are specific to A. tumida. A further source for $B t$ toxins could be larvae, which died of bacterial infestations, e.g. in beehives and in laboratory rearing programs (Neumann et al. 2001; Muerrle and Neumann 2004). According to the high probability to find $B t$ in the soil (Martin and Travers 1989), we also propose to search for new strains, which are naturally infesting SHB in its endemic and new ranges. Such strains could provide an alternative approach for the control of this honeybee pest.

Acknowledgments We like to thank B. Barth for technical assistance and S. Gisler from Andermatt Biocontrol AG for providing Novodor ${ }^{\circledR}$ and Jackpot ${ }^{\circledR}$. Financial support was granted by an Emmy Noether fellowship of the DFG [PN]. 


\section{References}

Bernhard K, Jarrett P, Meadows M, Butt P, Ellis DJ, Roberts GM, Pauli S, Rodgers P, Burges HD (1997) Natural isolates of Bacillus thuringiensis: Worldwide distribution, characterization, and activity against insect pests. J Invert Pathol 70:59-68

Ellis JD, Neumann P, Hepburn HR, Elzen PJ (2002) Longevity and reproductive success of Aethina tumida (Coleoptera: Nitidulidae) fed different natural diets. J Econ Entomol 95:902-907

Elzen PJ, Baxter JR, Westervelt D, Randall C, Delaplane KS, Cutts L, Wilson WT (1999) Field control and biology studies of a new pest species, Aethina tumida Murray (Coleoptera, Nitidulidae), attacking European honey bees in the Western Hemisphere. Apidologie 30:361-366

Feitelson JS, Payne J, Kim L (1992) Bacillus thuringiensis: Insects and Beyond. Biotechnology 10:271-275

Gill SS, Cowles EA, Pietrantonio PV (1992) The mode of action of Bacillus thuringiensis endotoxins. Ann Rev Entomol 37:615-636

Hepburn HR, Radloff SE (1998) Honeybees of Africa. Springer, Berlin Heidelberg New York

Hood WM (2004) The small hive beetle, Aethina tumida: a review. Bee World 85:51-59

Höfte H, Whiteley HR (1989) Insecticidal crystal proteins of Bacillus thuringiensis. Microbiol Rev 53:242-255

Krieg A (1986) Bacillus thuringiensis, ein mikrobielles Insektizid, Grundlagen und Anwendung. Acta Phytomedica 10, Beiheft zur Phytopathologischen Zeitung, Paul Parey, Berlin und Hamburg
Martin PAW, Travers RS (1989) Worldwide abundance and distribution of Bacillus thuringiensis isolates. Appl Environ Microbiol 55:2437-2442

Muerrle T, Neumann P (2004) Mass production of small hive beetles (Aethina tumida Murray, Coleoptera: Nitidulidae). J Apic Res 43:144-145

Naimov S, Weemen-Hendriks M, Dukiandjiev S, de Maagd RA (2001) Bacillus thuringiensis Delta-Endotoxin Cry1 hybrid proteins with increased activity against the Colorado potato beetle. Appl Environ Microbiol 67:5328-5330

Neumann P, Elzen P (2004) The biology of the small hive beetle (Aethina tumida Murray, Coleoptera: Nitidulidae): Gaps in our knowledge of an invasive species. Apidologie 35:229-247

Neumann P, Pirk CWW, Hepburn HR, Elzen PJ, Baxter JR (2001) Laboratory rearing of small hive beetles (Aethina tumida). J Apic Res 40:111-112

Pettis JS (2003) A scientific note on Varroa destructor resistance to Coumaphos in the United States. Apidologie 35:91-92

Schmolke MD (1974) A study of Aethina tumida: the small hive beetle. Project Report, University of Rhodesia, pp 178

Slaney AC, Robbins HL, English L (1992) Mode of action of Bacillus thuringiensis toxin CryIIIA: An analysis of toxicity in Leptinotarsa decemlineata (Say) and Diabrotica undecimpunctata howardi Barber. J Insect Biochem Mol Biol 22:9-18

Schnepf E, Crickmore N, van Rie J, Lereclus D, Baum J, Feitelson J, Zeigler DR, Dean DH (1998) Bacillus thuringiensis and its pesticidal crystal proteins. Microbiol Mol Biol Rev 62:775-806

Tabashnik BE (1994) Evolution of Resistance to Bacillus thuringiensis. Ann Rev Entomol 39:47-79 